\title{
Ownership Structure and Timeliness of Corporate Internet Reporting (TOCIR): Case of Kuwait
}

\author{
Mejbel Al-Saidi ${ }^{1}$ \\ ${ }^{1}$ Associate professor, Accounting department, PAAET, Kuwait \\ Correspondence: Mejbel Al-Saidi, Associate professor, Accounting department, PAAET, Kuwait. E-mail: \\ AL-SaidiMTMT@hotmail.com
}

Received: July 6, 2020

Accepted: August 10, 2020

Online Published: September 16, 2020

doi:10.5539/ijbm.v15n10p60

URL: https://doi.org/10.5539/ijbm.v15n10p60

\begin{abstract}
This study examines the impact of ownership structure on the timeliness of corporate internet reporting (TOCIR) index in the case of non-financial firms listed on the Kuwait Stock Exchange (KSE) by using a sample of 80 firms in 2019 and 4 ownership variables, namely, ownership concentration by large shareholders, ownership concentration by institutions, ownership concentration by the government, and ownership concentration by families (individuals). The results indicate that ownership concentration by large shareholders and ownership concentration by the government affected TOCIR, whereas ownership concentration by institutions and families (individuals) did not. To the best of the authors' knowledge, this study is the first study that examines the impact of ownership concentration on the timeliness of the corporate internet reporting in Kuwait.
\end{abstract}

Keywords: Ownership structure, Timeliness of corporate internet reporting, Kuwait

\section{Introduction}

The purpose of this study is to examine the impact of ownership structure on the timeliness of corporate internet reporting (TOCIR) in cases of non-financial firms listed on the Kuwait Stock Exchange (KSE). Around the world, ownership is divided into two types: concentrated or dispersed ownership. In a developing country like Kuwait, the ownership is usually concentrated, and large shareholders own the majority of firms' shares and control the voting rights. Agency theory argues that large shareholders are an important mechanism that may impact the firm's value and level of disclosure (Jensen \& Meckling, 1976). Meanwhile, timeliness is also important for listed firms. The OECD (2004, p. 22) stated that:t "The corporate governance framework should ensure that timely and accurate disclosure is made on all material matters regarding the corporation, including the financial situation, performance, ownership, and governance of the company."

Al-Shammari and Al-Saidi (2015) argued that the internet has grown, becoming an important method for presenting financial statements and financial data for investors in Kuwait. Abdelsalam, Bryant, and Street (2007) documented that the internet provides firms in all countries with a good channel for presenting their voluntary disclosures to investors. Consistent with this view, in 2003 the International Federation of Accountants (IFAC) encouraged firms to develop a corporate internet reporting policy to improve the level of disclosure of timely information. IFAC (2003) also recommended that listed firms update their information and financial data on their websites. Thus, the timeliness of corporate internet reporting (TOCIR) is an important topic. To test this topic, this study used a sample of 80 non-financial firms listed on the Kuwait Stock Exchange (KSE) at the end of 2019.

According to current Kuwaiti law, listed firms must disclose all large shareholders who own more than 5\% (directly or indirectly). This disclosure must also be included on the KSE website and in the firms' annual reports. The ownership structure in Kuwait is highly concentrated and divided into three major shareholders-namely, institution investors, government investors, and family (individual) investors - as well as a large number of small shareholders. Al-Shammari (2005) argued that Kuwait's stock market is dominated by three investor holding categories. Hamdan and Al-Sartawi (2013) found that the ownership concentration by institutions was about $46 \%$. Al-Saidi (2013) found that institutions' concentration is equal to $47 \%$ while the government ownership equals $3 \%$ and ownership concentration by families and individuals equals $6 \%$. 
This study focuses on Kuwait firms for three reasons. First, this study is the first of its kind to examine the impact of ownership concentration on TOCIR, thereby filling the gap identified by previous studies. Second, Kuwait's government and regulators have recently introduced new rules related to corporate governance, namely, the New Companies Law (NCL) in 2012, the Capital Authority Market (CAM) in 2013, and the corporate governance principles in 2016. This study is an opportunity for groups to regulate the rules and increase disclosure levels. Third, the KSE is one of the oldest markets in the Gulf area; thus, the results of this study would be useful not only to Kuwait's firms, but also all firms in the Gulf area, as they have the same business environment and rules. Therefore, the remainder of this study is organized as follows. Section 2 reviews the literature and hypothesis development. Section 3 presents the research design, and Section 4 outlines the study results and discussion. Finally, Section 5 concludes the study.

\section{Literature Review and Hypothesis Development}

Generally speaking, there are two major arguments related to ownership concentration from the agency theory perspective. The first type is the argument that separating ownership and control leads to agency conflict between managers and shareholders; thus, large shareholders play a significant role in monitoring and controlling management, which is the monitoring hypothesis (Jensen \& Meckling, 1976). Meanwhile, the second type, put forth by La Porta et al. (1998), asserts that there is another conflict between large and small shareholders and between large shareholders and debtholders, particularly in developing countries; this is the expropriation hypothesis. Such conflict gives large shareholders greater power and motivation to act in their interests only and reduce the level of disclosure, as they can easily access any disclosure they need and thus do not need to disclose the information to the public and pay more money. Al-Shammari, Brown, and Tarca (2008) stated that, in Kuwait and Gulf Co-Operation Council (GCC) countries, three big shareholders are considered insiders because they have the ability to get access to any information through their representatives on the board of directors. The GCC includes six countries: Kuwait, Bahrain, UAE, Saudi Arabia, Oman, and Qatar.

Regarding internet reporting, Al-Shammari and Al-Saidi $(2015$, p. 47) stated that, "although there [has been] a growing number of empirical studies measuring the disclosure of corporate internet reporting and its determinants since 1995, few studies have focused on the timeliness of corporate internet reporting." Current studies from developed and developing countries have produced mixed results related to this topic, because they have used different measures, different business environments, and different ownership structures, providing good motivation to study the situation in Kuwait, which may produce different results and conclusions. Pircheggar and Wagenhofer (1999) conducted the first empirical study examining TOCIR. They examined the use of the internet to present financial information in Australia and Germany from 1997 to 1998 and found that, in both countries, $66 \%$ of firms disclosed their information on websites. Lybaert (2002) studied the situation in 188 Dutch listed firms in 2000 and used eight groups to measure the timeliness of disclosed information: date of last update, current information, share quote, updated quote during the day, standard request, annual reports mailings, specific requests, and day of the response. Standard requests were the most common (i.e., $76 \%$ ). Meanwhile, Davey and Homkajohn (2004) examined the same issue in Thai listed firms and measured timeliness using four measures: press release existence, unedited latest, stock quote, and forward-looking statement. They found that press release existence was most common, with $89 \%$. Marston and Polei (2004) examined timeliness in German firms using Pircheggar and Wagenhofer's (1999) five criteria and found different results. Abdelsalam and Street (2014) studied the issue in UK listed firms using several governance and control variables as well as an 11-item timeliness index; they found that board independence is negatively related to the timeliness of corporate internet reporting. Abdelsalam and El-Masry (2008) examined the timeliness of corporate internet reporting for 44 listed firms in Ireland. By using Abdelsalam and Street's (2014) index items, the study found that board independence and managerial ownership positively affect the timeliness of corporate internet reporting.

In the case of Kuwait and after an intensive search, the author found only one study, by Al-Shammari and Al-Saidi (2015), that examined the impact of corporate governance and firm characteristics on the timeliness of corporate internet reporting using 11 items for TOCIR. They found that the level of timeliness increased with a smaller board, an independent board, and greater ownership concentration by large shareholders and concluded that corporate governance mechanisms and firm characteristics affect the level of timeliness of corporate internet reporting due to the conflicts of interest and information asymmetry within firms. However, the authors failed to consider other large shareholders.

Table 1 divides the ownership structure into four variables: ownership concentration by large shareholders, ownership concentration by institutions, ownership concentration by the government, and ownership concentration by families (individuals). The literature examining the impact of ownership concentration by large 
shareholders (block holders) has produced mixed results. For example, Abdelsalam and Street (2014) and Kamau and Waweru (2013) found that ownership concentration by large shareholders (block holders) negatively affects the timeliness of corporate internet reporting. However, Al-Shammari and Al-Saidi (2015), Abdelsalam and El-Masry (2008), Ezat and El-Masry (2008), Razak and Zarei (2015), and Lim (2012) found the opposite impact. Meanwhile, many other studies have found no significant relationship between the two variables, including Hassan and Magdy (2014), Yap, Saleh, and Abessi (2011), Hezadeen, Djamhuri, and Widya (2016), Yassin (2017), and Nawal (2018). These differences in the results are due to the differences in business environments, regulations, ownership structure, corporate governance systems, and measurement of variables.

Table 1. Previous studies examining the impact of ownership structure on TOCIR

\begin{tabular}{llll}
\hline Authors & TOCIR & Sample & Main results \\
\hline Hassan and Magdy (2014) & $72 \%$ & 139 firms, 2014, KSA & OC(non), FS(+), DT(-) \\
Abdelsalam and Street (2014) & --- & 115 firms, UK & OC(non) \\
Marston and Polei (2004) & --- & 50 firms, 2000/2003, Germany & OCG(-), FS(+) \\
Kamalluarifin (2016) & $65.5 \%$ & 95 firms, 2012, Malaysia & FS(non), DT(+) \\
Al-Shammari and Al-Saidi (2015) & $39 \%$ & 147 firms, 2012, Kuwait & OC(+), FS(+), DT(non) \\
Abdelsalam and El-Masry (2008) & $46 \%$ & 44 firms, Ireland & OC(+), FS(non), DT(non) \\
Ezat and El-Masry (2008) & ----- & 37 firms, 2006, Egypt & OC(+), FS(+), DT(+) \\
Hossain et al. (2012) & $52.5 \%$ & 42 firms, 2009, Qatar & FS(+) \\
Yap et al. (2011) & 21.1 & 306 firms, 2008, Malaysia & OC(non) \\
Hezadeen et al. (2016) & $53 \%$ & 137 firms, 2015, Indonesia & OC(non) \\
Al-Sartawi (2018) & $77 \%$ & 274 firms, 2016, GCC & OCI(non), DT(non), FS(+) \\
Razak and Zarei (2015) & $63.3 \%$ & 90 firms, 2013, KSA & OC (+), OCG(non ) \\
Xiao et al. (2004) & $68 \%$ & 300 firms, China, 2002 & FS(+), OCG(-), DT(+) \\
Kamau and Waweru (2013) & $68.2 \%$ & 48 firms, Kenya, 2010 & OC(-), FS(non) \\
Lim (2012) & $31 \%$ & 3504 firms, 1996/2009, Malaysia & OCI(+), \\
Yassin (2017) & $46.9 \%$ & 228 firms, 2011, Jordan & OCF(non) \\
Nawal (2018) & $51.5 \%$ & 170 firms, 2014, KSA & OC(non), \\
\hline OC-ow(-), DT(-) & OCG(non) \\
\hline
\end{tabular}

Notes. $\mathrm{OC}=$ ownership concentration by large shareholders, $\mathrm{OCI}=$ ownership concentration by institutions, $\mathrm{OCG}=\mathrm{ownership}$ concentration by government, $\mathrm{OCFI}=$ ownership concentration by families and individuals, $\mathrm{DT}=\mathrm{debt}, \mathrm{FS}=$ firm size.

In terms of institutional investors, empirically, Lim (2012) studied the impact of institutional ownership on the timeliness of corporate internet reporting and found a positive association. However, Al-Sartawi (2018) and Nawal (2018) found no empirical results supporting this view for the firms. However, studies related to the impact of government ownership on the timeliness of corporate internet reporting are very limited. For example, Marston and Polei (2004), Xiao, Yang, and Chow (2004), and Lim (2012) studied this relationship in different countries and found that government ownership negatively affects the timeliness of corporate internet reporting. Nawal (2018) studied the situation in Saudi Arabia and found no significant impact of government ownership on the timeliness of corporate internet reporting. These studies asserted that the government is usually subject to social goals and public pressure from society, and it may work according to these factors; thus, performance and disclosure are not government priorities.

In terms of families' (individuals') ownership, although Jensen and Meckling (1976) argued that conflicts of interest would be reduced in family firms because the managers and shareholders are the same person, others argued that family members may have access to firms' inside information, which gives them the authority to monitor managers without disclosing the information to the public (Al-Shammari et al., 2008). Lim (2012) examined the impact of families' (individuals') ownership on the timeliness of corporate internet reporting in 
Malaysian listed firms and found no significant relationship between the two variables. As agency theory presents two arguments and empirical studies have produced mixed results, to achieve the objectives of this study, the following hypotheses are presented:

H1: Ownership concentration by large shareholders (block holders) has a significant impact on the TOCIR.

H2: Ownership concentration by institutions has a significant impact on the TOCIR.

H3: Ownership concentration by the government has a significant impact on the TOCIR.

H4: Ownership concentration by families (individuals) has a significant impact on the TOCIR.

\section{Research Design}

The study sample was drawn from non-financial firms listed on the KSE. According to the KSE's website, there were 174 listed firms on December 31, 2019. After excluding the financial firms (banks, investment firms, and insurance firms), which have a different capital stature, the total number of non-financial firms listed equals 104 firms. In addition, some non-financial firms were excluded because they had no data available. Thus, our final sample was 80 firms, or $77 \%$ of total non-financial listed firms. This particular year was coming for two reasons. First, before the year 2017 there were no corporate governance rules, and many Kuwaiti listed firms did not fully comply with the new rules until mid-2018. Thus, including the years of 2017 and 2018 would be not relevant because of the different corporate governance rules. Second, ownership data is not available in Kuwait, and there is no database that organizes this type of data. The researchers collected these data manually from the KSE website between 27 of December 2019 to 31 of December 2019, since these days are holidays in Kuwait. The study sample is presented in Table 2 .

Table 2. Study sample

\begin{tabular}{llll}
\hline Sector & Total firms & Excluded firms & Included firms \\
\hline Oil and gas & 6 & 1 & 5 \\
Basic materials & 4 & 1 & 3 \\
Manufacturing & 29 & 9 & 20 \\
Consumer goods & 3 & -- & 3 \\
Health care & 3 & -- & 3 \\
Consumer service & 14 & 2 & 12 \\
Communications & 5 & --- & 5 \\
Estate & 39 & 11 & 28 \\
Technology & 1 & --- & 1 \\
Total & 104 & 24 & 80 \\
\hline
\end{tabular}

To determine whether each of the non-financial listed firms had a website, the researcher first looked for the firm's address on the KSE website or used search tools (e.g., www.google.com). All non-financial firms in the sample had a website, and most used the internet to send information to their shareholders. The researcher collected data from the firms' websites from February 1 until April 30, choosing this period because, according to Kuwaiti rules, all listed firms must disclose an annual report that includes financial statements and non-financial data before 31 of March each year; otherwise, the firms are suspended from KSE trading. However, at the time of writing this study, 24 non-financial firms had not publicized their financial data, which reduced our sample to 80 firms. For the purpose of this study, an ordinary least square (OLS) regression analysis was used to examine the impact of ownership concentration based on four variables related to the timeliness of corporate internet reporting. The following regression model was employed:

TOCIR $=\alpha+\beta 1 \mathrm{OC}++\beta 2 \mathrm{OCI}+\beta 3 \mathrm{OCG}+\beta 4 \mathrm{OCFI}+\beta 5 \mathrm{DT}+\beta 6 \mathrm{FS}+\beta 7 \mathrm{IND}+\varepsilon$

The timeliness of the corporate internet reporting index (TOCIR) index was the dependent variable. This study used the 11-item checklist that Al-Shammari and Al-Saidi (2015) developed [2], which includes a current press release or news, link to regulatory news services, current share price, calendar for future financial events, pages indicating the latest updates, monthly or weekly sales or operating data, market share of key products, current dividends, date of last website update, interim financial reports, and option to register for future e-mail alerts. Al-Shammari and Al-Saidi (2015) mentioned that their dependent variable was developed based on the studies of Abdelsalam and Street (2014), Davey and Homkajohn (2004), and Pircheggar and Wagenhofer (1999).

The timeliness for each firm's website was carefully reviewed and scored 1 if the firm disclosed it on the website 
and 0 otherwise. Then, the score for each firm was added to find the final score, and the TOCIR index was calculated by dividing the sum of the information items obtained from the firm by the total items on the checklist. This study used four ownership variables as independent variables: ownership concentration by large shareholders (OC), ownership concentration by institutional shareholders (OCI), ownership concentration by the government (OCG), and ownership concentration by families or individuals (OCFI), and three control variables: debt ratio (DT), firm size (FS), and industry type according the KSE classification (IND). Table 3 presents more details about the independent and control variables.

Table 3. Summary of independent and control variables

\begin{tabular}{|c|c|}
\hline Variables & Proxy \\
\hline $\begin{array}{l}\text { Ownership concentration by large } \\
\text { shareholders (OC) }\end{array}$ & $\begin{array}{l}\text { The percentage of common shares held by large shareholders } \\
\text { (more than } 5 \% \text { ) }\end{array}$ \\
\hline $\begin{array}{l}\text { Ownership concentration by institutions } \\
\text { (OCI) }\end{array}$ & $\begin{array}{l}\text { The percentage of common shares held by the institution (more } \\
\text { than } 5 \% \text { ) }\end{array}$ \\
\hline $\begin{array}{l}\text { Ownership concentration by government } \\
\text { (OCG) }\end{array}$ & $\begin{array}{l}\text { The percentage of common shares held by the government (more } \\
\text { than } 5 \% \text { ) }\end{array}$ \\
\hline $\begin{array}{l}\text { Ownership concentration by families or } \\
\text { individuals (OCFI) }\end{array}$ & $\begin{array}{l}\text { The percentage of common shares held by families or individuals } \\
\text { (more than } 5 \% \text { ) }\end{array}$ \\
\hline Debt (DT) & Total debt / total assets \\
\hline Firm size (FS) & Total assets \\
\hline Industry type (IND) & Dummy variable according to the KSE classification (nine sectors) \\
\hline
\end{tabular}

\section{Results and Discussion}

Consistent with Brooks (2014), the OLS assumptions must be tested because ignoring these assumptions would affect the coefficient of the study's regressions, thereby introducing misleading decisions. Table 4 indicates that all significant relationships among the independent variables (ownership variables, debt, and firm size) are less than $80 \%$; thus, multicollinearity is not a problem in this study (Brooks, 2014). However, there are some problems in the assumption of normality and homoscedasticity after looking at the skewness and kurtosis statistics in Table 6 as well as the analysis of residuals, plots of the studentized residuals against predicted values, and Q-Q plots. Thus, three variables - ownership concentration by the government, ownership concentration by families (individuals), and firm size-were transformed using normal scores consistent with several studies, including Haniffa, and Cooke (2002), Haniffa and Hudaib (2006), and Brooks (2014). Haniffa and Hudaib (2006) argued that the data are normal when the skewness is \pm 1.96 and kurtosis is \pm 3 ; however, Brooks (2014) argued that the data are normal when the skewness is zero and kurtosis is around.

Table 4. Pearson correlation coefficients matrix for study variables

\begin{tabular}{lllllll}
\hline & TOCIR & OC & OCI & OCG & OCFI & DT \\
\hline TOCIR & 1 & & & & & \\
OC & $0.577^{* *}$ & 1 & & & & \\
OCI & $0.473^{* *}$ & $0.75^{* *}$ & 1 & -0.093 & 1 & \\
OCG & -0.167 & 0.138 & $-0.405^{* *}$ & -0.145 & 1 & 1 \\
OCFI & 0.186 & 0.159 & -0.104 & -0.088 & $0.238^{*}$ & 1 \\
DT & 0.011 & 0.056 & -0.062 & 0.160 & -0.103 & $0.277^{*}$ \\
FS & 0.082 & -0.04 & 1 & \\
\hline
\end{tabular}

Notes: $* * *, * *$, and $*$ Significant at the $0.01,0.05$, and 0.10 levels, respectively (two-tailed).

For definitions of the variables, see Table 3.

The dependent variables' information is presented in Tables 5 and 6 . The overall mean value of the TOCIR index is $50 \%$ (range $=27 \%$ to $81 \%$ ), suggesting large variations in publishing timely corporate internet reports. In addition, none of the firms fully responded to investors' needs on the index. The highest score, $90 \%$, was for current share price (item three), followed by the second item (link to the regulatory news services) and item 11 (option to register for future e-mail alerts). Meanwhile, firms preferred to disclose items one and three (current press release or news and current share price), with $80 \%$ and $90 \%$, respectively. Abdelsalam and El-Masry (2008) 
argued that items one and three are very important to different stakeholders that help with making rational decisions.

The mean value of the TOCIR index in this study is greater than the value Al-Shammari and Al-Saidi (2015) found in Kuwait (i.e., 39\%), which means that internet disclosure has increased since 2012. However, the value of the TOCIR index is lower in Saudi Arabia (Hassan \& Magdy, 2014; Nawal, 2018; Razak \& Zarei, 2015), which were $73 \%, 63.3 \%$, and $51.5 \%$, respectively. The value of the TOCIR index in this study is also less than that in Malaysia, Indonesia, Jordan, Egypt, and Qatar (Yap et al., 2011; Hezadeen et al., 2016; Yassin, 2017; Ezat \& El-Masry, 2008; Hossain, Momin, \& Leo, 2012). Such results confirmed that the disclosure of timely corporate internet reporting needs to be regulated and improved (Al-Shammari \& Al-Saidi, 2015).

Table 5. Descriptive analysis for dependent variables (TOCIR) index

\begin{tabular}{lll}
\hline Category & Firms & Scores \\
\hline Current press release or news & 64 & 0.80 \\
Link to regulatory news services & 20 & 0.25 \\
Current share price & 72 & 0.90 \\
Calendar of future financial events & 48 & 0.60 \\
Pages indicated the latest updates & 40 & 0.50 \\
Monthly or weekly sales or operating data & 24 & 0.30 \\
Market share of key products & 24 & 0.30 \\
Current dividends & 36 & 0.45 \\
Date of last website update & 52 & 0.65 \\
Interim financial reports & 40 & 0.50 \\
Option to register for future e-mail alerts & 20 & 0.25 \\
\hline
\end{tabular}

Table 6. Descriptive statistics for study variables

\begin{tabular}{|c|c|c|c|c|c|c|c|}
\hline Variables & Sample & Mean & SD & Max & Min & Skewness & Kurtosis \\
\hline TOCIR & 80 & 0.50 & 0.13 & 0.81 & 0.27 & 0.419 & -0.767 \\
\hline $\mathrm{OC}$ & 80 & 0.57 & 0.22 & 0.96 & 0.09 & -0.201 & -0.917 \\
\hline OCG & 80 & 0.04 & 0.11 & 0.68 & 0 & 4.121 & 18.085 \\
\hline OCFI & 80 & 0.09 & 0.147 & 0.59 & 0 & 1.960 & 3.077 \\
\hline
\end{tabular}

Notes. For definitions of the variables, see Table 3.

Table 6 shows that the total ownership concentration by large shareholders was $57 \%$, compared to $45 \%$, 4\%, and $9 \%$ for institutions, government, and families (individuals), respectively. This is consistent with the findings of La Porta, Lopez-de-Silanes, Schleifer, and Vishny (1998), who argued that countries with low legal protections for listed firms, especially developing countries, have more ownership concentration. Al-Saidi (2013) studied a sample of non-financial listed firms from 2009 to 2012 and found that total ownership concentration equaled $56 \%$, while institutions, government, and families' (individuals') ownership equaled 47\%, 3\%, and 6\%, respectively. Al-Shammari and Al-Saidi (2015) found that the total ownership concentration for all firms (financial and non-financial) was $45 \%$. In terms of control variables, the mean value of debt was $45 \%$ in the current study, while the mean value of total assets equaled KD231 (one US dollar $=0.310 \mathrm{KW}$ dinar).

Table 7 presents the regression coefficients of the empirical results for ownership concentration's effect on the timeliness of corporate internet reporting. This study used multiple OLS regressions to examine this impact on 80 non-financial firms listed on the KSE at the end of 2019. The regression was significant at the 0.01 level; $\mathrm{R}^{2}$ equaled 0.60 , while the adjusted- $\mathrm{R}^{2}$ equaled 0.51 and the F-value equaled 6.969 . Thus, 0.51 of the variations of the timeliness of corporate internet reporting can be explained by the independent and control variables. According to Cohen (1992), if the $\mathrm{R}^{2}$ is more than 0.26 , the results are high effect sizes, so it is better to explain the outcome variables. Hypothesis 1 predicted that ownership concentration by large shareholders significantly affected the timeliness of corporate internet reporting, thus supporting this hypothesis. Ownership concentration was significantly associated with the timeliness of corporate internet reporting $(\beta=0.548, p<0.01)$. This positive 
relationship is consistent with the findings of Shleifer and Vishny (1986), who argued that the existence of large shareholders leads to better control and monitoring. Thus, more ownership concentration leads to better timeliness of corporate internet reporting for Kuwaiti listed firms. One reason for this result is that large shareholders try to reduce conflicts of interest with small shareholders, thereby increasing the timeliness of corporate internet reporting to give small shareholders the opportunity to monitor the managers' behaviors and activities. These results are consistent with those of Abdelsalam and El-Masry (2008), Al-Shammari and Al-Saidi (2015), Ezat and El-Masry (2008), and Razak and Zarei (2015).

The second hypothesis predicted that institutional ownership significantly affects the timeliness of corporate internet reporting. However, the study found a non-significant relationship between the two variables $(\beta=0.141$, $p>0.10$ ). Thus, Hypothesis 2 was rejected. The results indicated that institutional investors do not affect the timeliness of corporate internet reporting in Kuwait. This is probably because the institutions are insider investors who have easy excess to all information through their directors on the boards; as a result, disclosing more information via websites is unimportant to them. Thus, institutional investors may believe that there is no logical reason to pay more money to disclose the information to the public through firms' websites (Xiao et al., 2004). These results are consistent with those of Al-Sartawi (2018) and Nawal (2018).

Table 7. Ordinary least square (OLS) results

\begin{tabular}{|c|c|c|c|c|}
\hline \multirow{2}{*}{$\begin{array}{l}\mathrm{R}^{2}=0.60 \\
\text { Variables }\end{array}$} & \multirow[b]{2}{*}{ Expected relationship } & \multicolumn{2}{|c|}{ Adjustment $\mathrm{R}^{2}=0.51$} & \multirow{2}{*}{$\begin{array}{c}\text { F-Value }=6.969 \\
\text { The result }\end{array}$} \\
\hline & & Coefficients & T-Value & \\
\hline Constant & & 0.145 & $2.103 * *$ & \\
\hline OC & Significant & 0.548 & $3.462 * * *$ & Positive \\
\hline OCI & Significant & 0.141 & 0.894 & Not significant \\
\hline OCG & Significant & -0.074 & $-2.807 * * *$ & Negative \\
\hline OCFI & Significant & -0.022 & -0.712 & Not significant \\
\hline DT & & 0.026 & $1.835^{*}$ & \\
\hline FS & & 0.036 & $2.567^{*}$ & \\
\hline IND1 & & 0.151 & $2.370^{*}$ & \\
\hline IND2 & & 0.152 & $2.462 *$ & \\
\hline IND3 & & 0.065 & 0.857 & \\
\hline IND4 & & 0.125 & $1.913 *$ & \\
\hline IND5 & & 0.010 & 0.139 & \\
\hline IND6 & & 0.062 & 0.857 & \\
\hline IND7 & & 0.207 & 1.552 & \\
\hline IND8 & & -0.067 & -0.772 & \\
\hline
\end{tabular}

Notes. $* * * * *$, and $*$ Significant at the $0.01,0.05$, and 0.10 levels, respectively. The excluded sector is sector nine (technology sector). For definitions of the variables, see Table 3 .

In terms of government ownership, the results listed in Table 7 reveal a significant negative relationship between government ownership and the timeliness of corporate internet reporting $(\beta=-0.074, p<0.01)$. Thus, Hypothesis 3 was supported. This is consistent with Ghazali and Weetman's (2006) finding that the government might disclose less information on websites to protect the political interests of their beneficial government owners and shareholders. The results of this study are consistent with those of Marston and Polei (2004), Xiao et al. (2004), and Lim (2012) - all of which argued that the government, like any large shareholder, can obtain all the necessary information without needing to post the information on firms' websites.

The final hypothesis predicted that ownership concentration by families (individuals) significantly affects the timeliness of corporate internet reporting; however, the results rejected this hypothesis $(\beta=-0.022, p>0.10)$. Thus, family (individual) ownership encouraged firms to disseminate timely information via their websites. There are two possible reasons for such results. First, as in the case of institutional shareholders, family (individual) shareholders are typically insiders in Kuwait, and they can access any type of information through their board representatives, so they do not need to disclose more information on the firms' websites and pay more money. The second reason is that Kuwait is a very small country where families' names are important; reducing the level at which online information can protect them from competitors. This is consistent with the study by Lim (2012), which found that family ownership plays no significant role in the timeliness of corporate internet reporting. Ghazali and Weetman (2006) also argued that there is entrenched behavior from family 
members about such information.

Regarding the control variables, the study found that debt and firm size positively affect the timeliness of corporate internet reporting, while industry variables produced mixed results. In terms of debt, this positive relationship indicates that creditors in Kuwait have demanded more information from Kuwaiti firms, which have increased their online information to satisfy creditors' needs while also reducing agency problems between large shareholders and creditors and showing their ability to pay their debts. Meanwhile, in terms of firm size, the main reason for such positive effects is because of the strong government and public pressure for large firms to publish more online information; otherwise, the firms would lose their reputation and creditability. These results are consistent with the studies of Kamalluarifin (2016), Hassan and Magdy (2014), Marston and Polei (2004), Al-Shammari and Al-Saidi (2015), Ezat and El-Masry (2008), Hossain et al. (2012), Al-Sartawi (2018), and Xiao et al. (2004).

\section{Conclusion}

This study examined the impact of ownership structure on the timeliness of corporate internet reporting in 80 non-financial firms listed on the KSE at the end of 2019. This study used the same index as Al-Shammari and Al-Saidi (2015) for the dependent variable to measure the timeliness of corporate internet reporting. It also used four ownership concentration variables-ownership concentration by large shareholders, ownership concentration by institutions, ownership concentration by the government, and ownership concentration by families (individuals) - as well as three control variables (i.e., debt, firm size, and industry type).

The study found that the mean value of the timeliness of corporate internet reporting index was $50 \%$, with a minimum value of $27 \%$ and a maximum value of $81 \%$. These results confirmed significant variations in publishing timely corporate internet reporting among non-financial firms listed on the KSE. These variations probably stem from the differences in ownership structures and firm-specific characteristics. The study found that the number of large shareholders positively affects the timeliness of corporate internet reporting, whereas ownership concentration by the government negatively affects it. However, the study found no empirical evidence that ownership concentration by institutions and families (individuals) affects the timeliness of corporate internet reporting. In addition, debt and firm size positively affect the timeliness of corporate internet reporting, while industry type impacts this variable in different ways.

After intensive searches, the author found only one study that examined the impact of corporate governance mechanisms on the timeliness of corporate internet reporting. Thus, this study makes two important contributions. First, it examined the timeliness of corporate internet reporting, which has become an important topic for many investors seeking to make rational decisions, in Kuwait. Thus far, small countries such as Kuwait have been ignored, and, thus, this study was conducted to fill that gap. Second, this study sought to confirm whether differences existed in the results of the impact of ownership concentration by large shareholders on the timeliness of corporate internet reporting in Kuwait and results found in other studies from developed and developing countries.

The results of this study have many implications for regulators, the government, listed firms, investors, and researchers. For regulators and the government, this study presented the strengths and weaknesses of corporate internet reporting among non-financial firms listed on the KSE; it also presented the important role of large shareholders in this disclosure. Thus, regulators and the government can modify current corporate governance rules and require all listed firms to publish their financial and non-financial data through the internet or alternatively adopt any corporate governance from a developing country (e.g., Oman - the first country in the Gulf area to have a corporate governance code). For listed firms and investors, the results of this study could be useful by increasing the level of online, timely, and accurate information on firms' websites, which may help local and foreign investors in their investment decisions.

Finally, in terms of academic researchers, this study has three limitations. First, the study used a sample of one year from non-financial listed firms. Second, the index measure that the timeliness of corporate internet reporting was based on was an unweighted checklist from the end of 2019. Third, the study focused on one aspect of corporate internet reporting, namely timeliness. Thus, to deal with these limitations, researchers can do the following further studies. First, researchers can use panel data, for example, from year 2020 to 2022; however, they must consider that the data of ownership structure on the KSE website is available for one year only (the latest year) and is collected manually. Second, using a weighted index to measure the timeliness of corporate internet reporting, using other aspects of online disclosure, and adding more variables would be very good opportunities for future studies. In addition, researchers can use one year before 2017 (when there were no corporate governance rules) and one year after 2017 (when there were new governance rules) and compare the 
differences between these two years in terms of the timeliness of corporate internet reporting.

\section{References}

Abdelsalam, O., \& El-Masry, L. (2008). The impact of board independence and ownership structure on the timeliness of corporate internet reporting of Irish-listed companies. Managerial Finance, 34(12), 907-918. https://doi.org/10.1108/03074350810915842

Abdelsalam, O., \& Street, D. (2014). Corporate governance and the timeliness of corporate internet reporting by UK listed companies. Journal of International Accounting, Auditing and Taxation, 16, 111-130. https://doi.org/10.1016/j.intaccaudtax.2007.06.001

Abdelsalam, O., Bryant, H., \& Street, L. (2007). An examination of comprehensiveness of corporate internet reporting provided by London listed companies. Journal of International Accounting Research, 6(2), 1-33. https://doi.org/10.2308/jiar.2007.6.2.1

Al-Saidi, M. (2013). Ownership concentration and firm performance: the case of Kuwait. Jordan Journal of Business Administration, 9(4), 803-819. https://doi.org/10.12816/0002094

Al-Shammari, B. A. (2005). Compliance with international accounting standards by listing companies by Gulf Cooperation Council member states: Empirical study (Unpublished doctoral thesis). The University of Western Australia, Australia.

Al-Shammari, B., \& Al-Saidi, M. (2015). Impact of corporate governance and company characteristics on the Timeliness of corporate internet reporting in Kuwait. Journal of The Gulf and Arabian Peninsula Studies, 157(41), 41-83. https://doi.org/10.34120/0382-041-157-008

Al-Shammari, B., Brown, P., \& Tarca, A. (2008). An investigation of companies with international accounting standards by listed companies in the Gulf Co-Operation Council member states. The International Journal of Accounting, 43(4), 425-447. https://doi.org/10.1016/j.intacc.2008.09.003

Brooks, C. (2014). Introductory econometrics for finance. UK: Cambridge University Press. https://doi.org/10.1017/CBO9781139540872

CMA. (2013). Capital Market Authority. Kuwait: Kuwait Stock Exchange.

Cohen, J. (1992). A power primer. Psychological Bulletin, 112, 155-159. https://doi.org/10.1037/0033-2909.112.1.155

Davey, H., \& Homkajohn, K. (2004). Corporate internet reporting: an Asian example. Problems and Perspectives in Management, 2(2), 211-227.

Ezat, A., \& El-Masry, A. (2008). The impact of corporate governance on the timeliness of corporate internet reporting. Managerial Finance, 34(12), 848-867. https://doi.org/10.1108/03074350810915815

Ghazali, H., \& Weetman, P. (2006). Perpetuating traditional influence: voluntary disclosure in Malaysia following the economic crisis. Journal of International Accounting, Auditing \& Taxation, 15, 226-248. https://doi.org/10.1016/j.intaccaudtax.2006.08.001

Hamdan, A., \& Al-Sartawi, A. (2013). Corporate governance and institutional ownership: Evidence from Kuwait's financial sector. Jordan Journal of Business Administration, 9(1), 191-203. https://doi.org/10.12816/0002053

Haniffa, R., \& Cooke, T. E. (2002). Culture, corporate governance and disclosure in Malaysian corporations. ABACUS, 38, 317-349. https://doi.org/10.1111/1467-6281.00112

Haniffa, R., \& Hudaib, M. (2006). Governance structure and firm performance of Malaysian companies. Journal of Business Finance and Accounting, 33, 1034-1062. https://doi.org/10.1111/j.1468-5957.2006.00594.x

Hassan, N., \& Magdy, A. (2014). Corporate characteristics, corporate governance and timeliness of corporate internet reporting: Evidence from Saudi Arabia listed companies. Journal of Accounting and Auditing, 2, $1-32$.

Hezadeen, A., Djamhuri, A., \& Widya, Y. (2016). Corporate governance and internet financial reporting. The International Journal of Accounting and Business Society, 24(2), 36-47. https://doi.org/10.21776/ub.ijabs.2016.024.2.03

Hossain, M., Momin, M., \& Leo, S. (2012). Internet financial reporting and disclosure by listed companies: further evidence from an emerging county. Corporate Ownership \& Control, 9(4), 351-366. https://doi.org/10.22495/cocv9i4c3art6 
IFAC. (2003). Rebuilding public confidence in financial reporting: an international perspective. Paper presented at the $2^{\text {nd }}$ Taipei corporate governance Forum. Taipei.

Jensen, M., \& Meckling, W. (1976). Theory of the firm: managerial behavior, agency costs and ownership structure. Journal of Financial Economics, 3, 305-360. https://doi.org/10.1016/0304-405X(76)90026-X

Kamalluarifin, W. (2015). The influence of corporate governance and firm characteristics on the timeliness of corporate internet reporting by top 95 companies in Malaysia. International Economics \& Business Management Conference, 35, 156-165. https://doi.org/10.1016/S2212-5671(16)00020-4

Kamau, R., \& Waweru, N. (2013). Corporate governance and level of internet reporting in Kenya. https://doi.org/10.2139/ssrn.2310098

La Porta, R., Lopez-de-Silanes, E., Shleifer, A., \& Vishny, W. (1998). Law and finance. Journal of Political Economy, 106, 1113-1155. https://doi.org/10.1086/250042

Lim, S. (2012). Ownership structure and concentration and the timeliness of corporate earnings: Malaysian evidence (Unpublished master's thesis). Queensland University of Technology, Australia.

Lybaert, N. (2002). On-line financial reporting: an analysis of the Dutch listed firms. International Journal of Digital Accounting Research, 2(4), 195-234. https://doi.org/10.4192/1577-8517-v2_7

Marston, C., \& Polei, A. (2004). Corporate reporting on the internet by German companies. International Journal of Accounting Information System, 5(3), 285-311. https://doi.org/10.1016/j.accinf.2004.02.009

Nawal, A. (2018). Corporate internet reporting, firm characteristics, corporate governance and firm financial performance of Saudi listed companies (Unpublished PHD thesis). University of Plymouth.

NCL. (2012). The new companies law. Kuwait: Ministry of Trade.

OECD. (2004). OECD principles of corporate governance. Paris: OECD. https://doi.org/10.22201/fca.24488410e.2005.562

Pircheggar, B., \& Wagenhofer, A. (1999). Financial information on the internet: a survey of the homepages of Austrian companies. European Accounting Review, 8(2), 383-395. https://doi.org/10.1080/096381899336113

Razak, R., \& Zarei, R. (2015). The influence of board characteristics and ownership structure on the extent of internet financial disclosure in Saudi Arabia. Journal of Emerging Trends in Economics and Management Sciences, 6(2), 158-168.

Sartawi, A. (2018). Does institutional ownership affect the level of online financial disclosure. Academy of Accounting and Financial Studies Journal, 22(2), 1-10.

Shleifer, A., \& Vishny, R. W. (1997). A survey of corporate governance. The Journal of Finance, 52(2), 737-783. https://doi.org/10.1111/j.1540-6261.1997.tb04820.x

Xiao, Z., Yang, H., \& Chow, W. (2004). The determinants and characteristics of voluntary internet-based disclosure by listed Chinese companies. Journal of Accounting and Public Policy, 23, 191-225. https://doi.org/10.1016/j.jaccpubpol.2004.04.002

Yap, K., Saleh, Z., \& Abessi, M. (2011). Internet financial reporting and corporate governance. Australian Journal of Basic and Applied Sciences, 5(10), 1273-1289.

Yassin, W. (2017). The determinants of internet financial reporting in Jordan: financial versus corporate governance. International Journal of Business Information System, 25(4), 536-556. https://doi.org/10.1504/IJBIS.2017.085176

\section{Copyrights}

Copyright for this article is retained by the author(s), with first publication rights granted to the journal.

This is an open-access article distributed under the terms and conditions of the Creative Commons Attribution license (http://creativecommons.org/licenses/by/4.0/). 